\title{
Bovine $\beta$-defensin gene family: opportunities to improve animal health?
}

\author{
K. G. Meade, ${ }^{1}$ P. Cormican, ${ }^{1}$ F. Narciandi, ${ }^{2}$ A. Lloyd, ${ }^{3}$ and C. O'Farrelly ${ }^{2}$ \\ ${ }^{1}$ Animal \& Bioscience Research Department, Animal \& Grassland Research and Innovation Centre, Teagasc, Grange, Co. \\ Meath, Ireland; ${ }^{2}$ Comparative Immunology Group, School of Biochemistry and Immunology, Trinity College, Dublin, Ireland; \\ and ${ }^{3}$ Department of Science \& Health, Carlow Institute of Technology, Co. Carlow, Ireland
}

Submitted 23 May 2013; accepted in final form 11 November 2013

\begin{abstract}
Meade KG, Cormican P, Narciandi F, Lloyd A, O’Farrelly C. Bovine $\beta$-defensin gene family: opportunities to improve animal health?. Physiol Genomics 46: 17-28, 2014. First published November 12, 2013; doi:10.1152/physiolgenomics.00085.2013.—Recent analysis of the bovine genome revealed an expanded suite of $\beta$-defensin genes that encode what are referred to as antimicrobial or host defense peptides (HDPs). Whereas primate genomes also encode $\alpha$ - and $\theta$-defensins, the bovine genome contains only the $\beta$-defensin subfamily of HDPs. $\beta$-Defensins perform diverse functions that are critical to protection against pathogens but also in regulation of the immune response and reproduction. As the most comprehensively studied subclass of HDPs, $\beta$-defensins possess the widest taxonomic distribution, found in invertebrates as well as plants, indicating an ancient point of origin. Cross-species comparison of the genomic arrangement of $\beta$-defensin gene repertoire revealed them to vary in number among species presumably due to differences in pathogenic selective pressures but also genetic drift. $\beta$-Defensin genes exist in a single cluster in birds, but four gene clusters exist in dog, rat, mouse, and cow. In humans and chimpanzees, one of these clusters is split in two as a result of a primate-specific pericentric inversion producing five gene clusters. A cluster of $\beta$-defensin genes on bovine chromosome 13 has been recently characterized, and full genome sequencing has identified extensive gene copy number variation on chromosome 27 . As a result, cattle have the most diverse repertoire of $\beta$-defensin genes so far identified, where four clusters contain at least 57 genes. This expansion of $\beta$-defensin HDPs may hold significant potential for combating infectious diseases and provides opportunities to harness their immunological and reproductive functions in commercial cattle populations.
\end{abstract}

$\beta$-defensin; bovine; fertility; immunology

KEY TO SUCCESSFUL DEFENSE against pathogens is the constitutive and inducible expression of small effector molecules of the innate immune response known as host defense peptides (HDPs). Originally classified as antimicrobial peptides (AMPs), HDPs are natural antibiotics $(43,120,160)$ and consist of three different subfamilies of peptides, classified according to their structure (80). Mammalian $\alpha$-defensins were originally found in macrophages from rabbit lung (118) and quickly thereafter in human neutrophils $(45,119)$. These molecules are also found in Paneth cells of the small intestine (100). Some primate genomes also contain theta $(\theta)$-defensins, which are lectins with broad-spectrum antiviral efficacy (79). Neither of these defensin subtypes are present in cattle (83), but it is a related family of small, cationic peptides subsequently found in bovine tracheal cells and neutrophils $(33,121)$, called $\beta$-defensins that are the focus of this review.

Traditionally, $\beta$-defensins were viewed as exclusively antimicrobial molecules providing front-line protection against pathogens. Their responsiveness to diverse bacterial, viral, and fungal infections supported this view $(23,88,134)$. Several

Address for reprint requests and other correspondence: K. G. Meade, Teagasc, Animal \& Grassland Research and Innovation Centre, Grange, Co. Meath, Ireland (e-mail: kieran.meade@teagasc.ie). mechanisms of antimicrobial action documented for $\beta$-defensins, including aggregation, pore formation, and prokaryotic membrane depolarization (111), have enabled these peptides to retain their potency against infectious agents throughout evolution (102). One of the first $\beta$-defensins to be discovered was bovine tracheal antimicrobial peptide (TAP) (33), which has since been associated with the early response to inflammation (23) and later shown to be expressed in the bovine mammary gland (109). As additional functions for $\beta$-defensins were determined $(17,151)$, a re-evaluation of the traditional view of them as exclusively antimicrobial agents occurred $(15,37)$. $\beta$-Defensins also have significant immunomodulatory functions (16) and serve as an important link between innate and adaptive immune responses $(2,105)$. Expression of $\beta$-defensins in the sterile environment of the developing embryo in a range of species $(87,91)$ suggests a potential role in development. Defensin-like genes in the Platypus genome encode major components of venom, suggesting an evolutionary link between antimicrobial and venom peptides (146). Further support for expanded $\beta$-defensin functions is witnessed in plants, where $>300$ defensin-like genes have been found in the Arabidopsis genome (129), and a specific cluster expressed in reproductive tissues are involved in male-female gamete interactions to facilitate fertilization (135). This latter finding con- 
curs with the strong evidence emerging for a similar role for these defensins in mammals, with hBD126 shown to regulate fertility in humans $(139,140)$.

\section{$\beta$-DEFENSIN GENE STRUCTURE, POSITIVE SELECTION, AND EVOLUTION}

$\beta$-Defensins are the ancestral gene from which $\alpha$-defensins arose in some mammals (150). However, their presence in marsupials, shows that $\alpha$-defensins must have been present very early in mammalian evolution and subsequently lost in most artiodactyls (83). The equine genome encodes a high number of functional $\alpha$-defensins $(18,19)$ that are not present in other members of this order studied to date (40). Only $\beta$-defensin genes have been found in birds $(56,84)$, and at least one $\beta$-defensin gene has been identified in all the vertebrate genomes so far sequenced, indicating that evolution of the gene family predates the divergence of fish from tetrapods (166). Recent sequencing of high-quality drafts of many more vertebrate genomes has facilitated a comparative genomics approach to characterize the $\beta$-defensin gene repertoire, and species-specific clades have been identified. Current estimates vary from $14 \beta$-defensin genes in chicken to 29 in pigs, 38 in dog, 33 in chimp, and 48 in mice and humans $(27,84,101,104$, 117), although the final number will be subject to change as more genomes are sequenced and correctly annotated.

Most $\beta$-defensin genes have a characteristic two exon structure, the first of which encodes a prepropeptide with a hydrophobic leucine-rich signal sequence, while the mature peptide is encoded by the second exon (Fig. 1). Multiple gene duplication events and subsequent sequence diversification in the mammalian lineage has resulted in a large family of $\beta$-defensin peptides with diverse amino acid sequence but virtually iden-

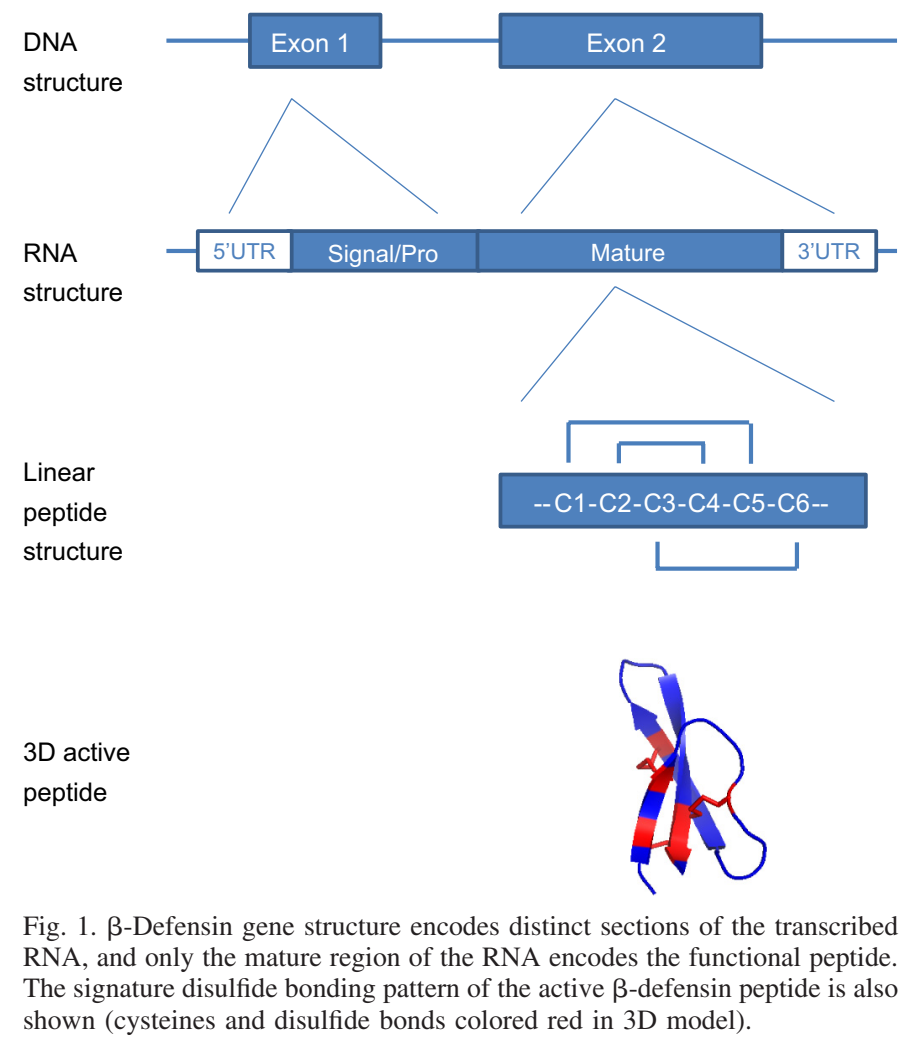

tical tertiary structure based on the characteristic intramolecular disulfide bonds (9). The specific $\mathrm{C} 1-\mathrm{C} 5, \mathrm{C} 2-\mathrm{C} 4$, and C3-C6 cysteine pairing, which is conserved across all $\beta$-defensins, indicates that the disulfide bonds are essential to the function of the molecule. Although human defensin derivatives with different cysteine pairings also have antimicrobial activity (63), the disulfide bonds maintain peptide stability by conferring resistance to proteolysis (20) and may also be important for the cell signaling and immunomodulatory functions of these molecules (125).

An unusually high degree of sequence variation in the mature peptide, even within closely related family members, implies extensive specialization and species-specific adaptation in $\beta$-defensins (122). Comparison of the rates of synonymous and nonsynonymous nucleotide substitution suggests that gene duplication was followed by a period of positive selection for diversification in the amino acid sequence of the mature peptide $(60,137)$, and this precipitated the emergence of multigene $\beta$-defensin loci in primates (123). Positively selected residues in the $\mathrm{NH}_{2}$ terminus of the human BD4 defensin peptide indicate involvement in oligomerization of these peptides (14), which could form another prospect for selection pressure to shape the diversity of modern $\beta$-defensins. This rapid divergence among second exon sequences contrasts with relative stasis found in the sequences of the first exon. Interestingly, divergent selection pressures have been detected within rodent and primate lineages for residues within the prepropeptide region of $\beta$-defensins (124). Selection for noncoding regulatory regions in $\mathrm{hBD} 103$ in human populations from Asia has also recently been described (54), which is thought to be a response to selection pressure from influenza viruses in the region. This represents a new dimension to natural selection for expression levels of a particular defensin protein, as distinct from selection for additional gene copies.

Several hypotheses have been proposed to account for the natural selection pressures that drove the expansion of these genes in particular lineages [for review, see Yeaman and Yount (155)] including the following:

1) The common threat hypothesis: structural similarities and retention of these genes across very divergent species throughout the course of evolution suggests that gene expansion forms part of a common survival strategy;

2) The immunosaltation hypothesis: sudden emergence of many new life forms (during the Cambrian explosion, $\sim 540$ million years ago) drove the development of specialized immune systems in response to new pathogenic challenges;

3) The niche adaptation hypothesis: development of specialized anatomical and physiological niches created a requirement for equally specialized immune responses (e.g., rumen development).

Expansion of the $\beta$-defensin gene repertoire in multiple species in response to a common pathogenic threat supports the view of $\beta$-defensins as front-line effectors against pathogenic insults across multiple tissues exposed to microbes including tongue and epithelial cells, as well as in primary immune cells: bovine neutrophils (121) and macrophages (110). Extensive $\beta$-defensin gene copy number variation $(\mathrm{CNV})$ has been shown in the human chromosome 8 cluster (orthologous to and syntenic with chromosome 27 in cattle), which influences transcript expression level (61). $\beta$-Defensin gene CNV has a documented association with disease resistance $(58,62)$; it is 
hypothesized that increasing defensin gene-copy number contributes to increased susceptibility to inflammatory or autoimmune diseases but is protective against infectious disease (59). More recent work also fits this model, showing that lower defensin gene-copy number contributes to reduced HIV load as a result of altered efficacy of Th17 lymphocyte recruitment to the site of infection $(53,54)$. The multiple immunomodulatory functions now emerging for $\beta$-defensins (discussed below) also support the common threat hypothesis that expansion of these genes occurred in response to multiple infectious disease challenges encountered by cattle over the course of their evolution. Of course, emergence of defensins in common ancestors during the Cambrian explosion (immunosaltation hypothesis) does not preclude subsequent gain and loss of specific genes or gene clusters as a result of speciation in response to divergent selection pressures. Expression of $\beta$-defensin genes in the absence of infection, such as in the developing embryo (87, 91 ), is potentially supportive of neofunctionalization of some $\beta$-defensin gene family members. However, the suggestion that the evolution of the rumen led to a requirement for more sophisticated immune mechanisms to manage the interface between microbes and the animal host $(38,90)$ is one that has gained support and fits under the "niche adaptation hypothesis." Rumen-specific defense mechanisms are important to ensure the balance between immune surveillance of the diverse gut microbiota (41) and the maintenance of the integrity of the gastrointestinal epithelial barrier (112). Bovine enteric $\beta$-defensin was originally found expressed in the small intestine and the colon (136). In sheep, maximal expression of $o B D I$ and $o B D 2 \beta$-defensins was detected in the rumen during the first $6-8 \mathrm{wk}$ of life and also in the digestive tract in the prenatal lamb $(64,91)$. This evidence would support a role for defensins in managing the microbial interface, especially during initial postnatal colonization of the intestine and rumen. It is tempting to speculate that in the absence of infection, lingual antimicrobial peptide (LAP) in bovine milk (67) may help regulate the microflora in the developing rumen of the postnatal calf, but this has not yet been established. A recent study showed downregulation of $L A P, T A P$, and DEFB4A (all chromosome $27 \beta$-defensins) expression in rumen epithelium in response to infusion with butyrate, a short chain fatty acid (7), suggesting a close association between dietary composition and HDP expression in the rumen.

Biological systems most affected by changes in the number and organization of genes in the cattle lineage include reproduction and immunity, as well as lactation and digestion (38). It is therefore likely that rather than a single event, multiple natural selection pressures have been exerted on the bovine genome over the course of evolution, leading the biological diversity in $\beta$-defensin gene repertoire now present. The divergent selection pressures (both positive and negative) detected between $\beta$-defensin sequences in rodents and primates $(60,124)$, as well as the diverse expression patterns in epithelial tissue and immune cells detected for the expanded chromosome 27 genes in cattle $(23,24,26,82,134,145)$, supports multiple events, which may include the development of the rumen. However, the chromosome 13 cluster of bovine $\beta$-defensin genes are preferentially expressed in reproductive tissues (97), indicating that their function is unlikely to be related to rumen development. It may be more likely that the herd structure in ruminants, which could promote rapid disease transmission, is also a contributory cause of the selection pressure for expanded $\beta$-defensin repertoires in cattle. Duplication and subsequent diversification of $\beta$-defensin genes in response to a common threat as a possible consequence of species-specific or clade-specific pathogenic insults faced by individual species during the course of their evolution are supported by the human literature $(54,60)$ and is likely to be also true in cattle (104).

\section{乃-DEFENSIN GENE EXPANSION IN CATTLE}

Bos taurus was one of the first species in which $\beta$-defensinlike molecules were discovered $(33,121,136)$. Eighteen complete and partial bovine $\beta$-defensin (bBD) sequences were identified through a combination of genomic sequence analysis (109) and direct sequencing of isolated purified proteins from blood neutrophils (121). This number was noticeably smaller than the numbers of purportedly functional $\beta$-defensin genes identified in other species subsequently by both in silico and laboratory methods $(27,101)$. However, subsequent comprehensive bioinformatic search of the bovine genome identified 57 open reading frames with the characteristic six-cysteine spacing of the $\beta$-defensin family of genes (29).

Synteny analysis based on gene sequence conservation with the human genome (which has the most reliable annotation) shows four distinct clusters of $\beta$-defensin genes within the bovine genome. Located on chromosomes 8 (cluster $A), 13$ (cluster B), 23 (cluster $C$ ), and 27 (cluster D), $\beta$-defensin gene sequences within a cluster tend to be more similar to each other than to genes in other clusters within the same species.

\section{Syntenic Cluster A}

Syntenic cluster A consists of four genes, namely bBD136, bBD131, bBD135, and bBD134, which span $93 \mathrm{~kb}$ on bovine chromosome 8 (Fig. $2 A$ ). This is a conserved mammalian cluster that with cluster $C$ arose at one site early in mammalian evolution. This ancestral cluster subsequently split in two, $\sim 180$ million years ago (10) when eutheria separated from marsupials to generate clusters $A$ and $C$. In contrast to clusters $B$ and $D, A$ and $C$ show little evidence of gene gain or loss in any eutherian mammals for which genome sequence data is available (101). This cluster is conserved in human and dog (dog being the closest relative to bovine with a completely sequenced and well-annotated genome) but is missing from the recent analysis of defensin genes in the pig (Sus scrofa) genome (27). However, close genomic matches exist in pig (at least for bBD131 and bBD135) and are not yet annotated (unpublished data). While expression of these genes has not been investigated in cattle to date, gene expression in the reproductive tract has been detected in rat epididymis (101).

\section{Syntenic Cluster B}

$\beta$-Defensin cluster $B$ is a relatively stable cluster in higher mammals with few gene gain or loss events disrupting the syntenic order and gene orientation established early in eutherian mammalian evolution (104). In the bovine genome, this newly discovered cluster spans $320 \mathrm{~kb}$ on chromosome 13 (29). Sixteen of these genes are conserved in a 1:1:1 orthologous relationship among human, dog, and bovine (Fig. 2B). Interestingly, the bovine genome appears to encode a number of relatively recent gene duplicates within this cluster com- 

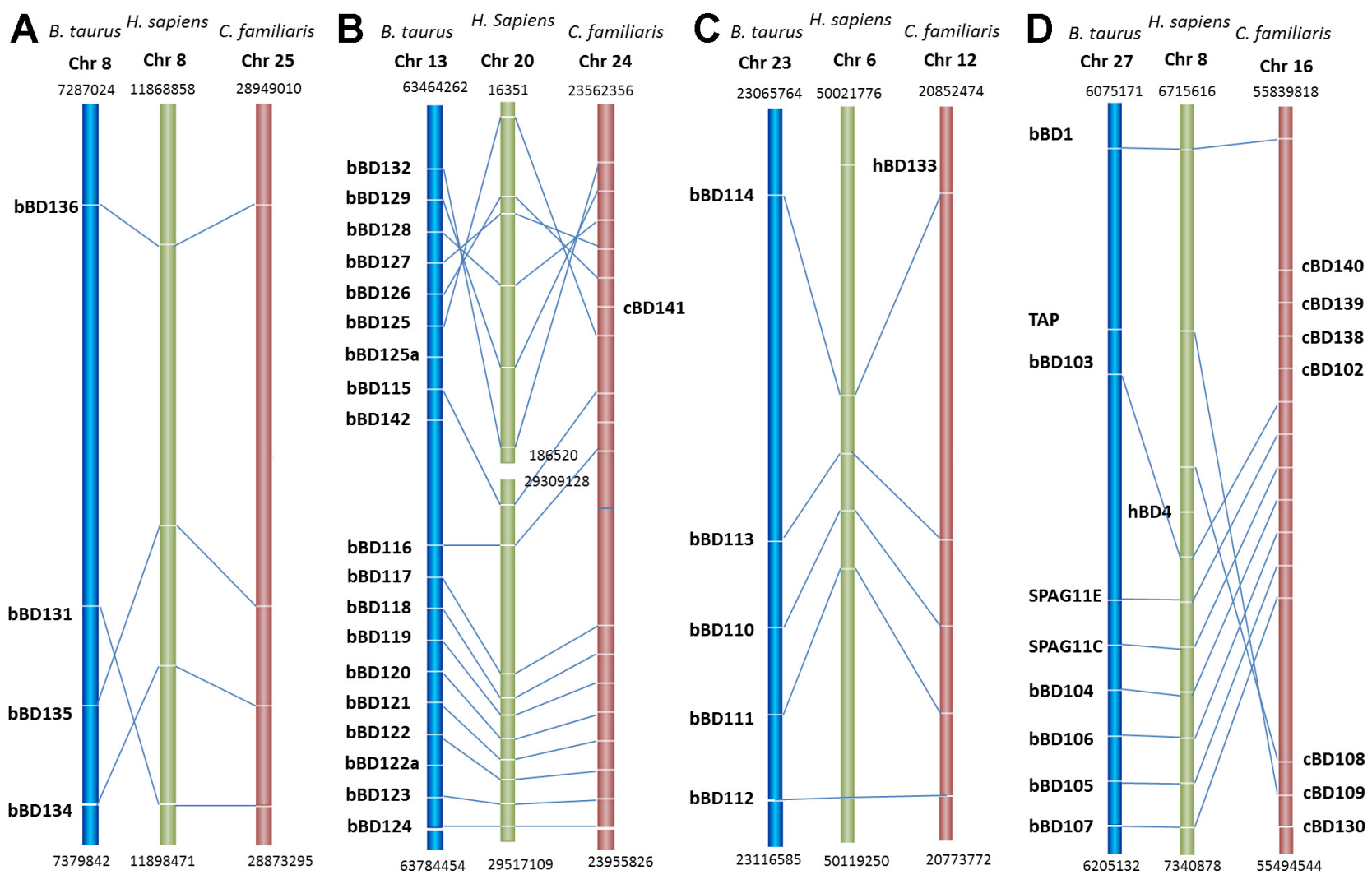

Fig. 2. Syntenic maps of bovine, human, and canine $\beta$-defensin genes in a direct 1:1 relationship with those in other species mapping to: bovine chromosome 8 (cluster $A)(A)$, bovine chromosome 13 (cluster B) $(B)$, bovine chromosome 23 (cluster $C)(C)$, bovine chromosome $27($ cluster $D)(D)$. Chromosomes are color coded according to species: Bos taurus in blue, Homo sapiens in green, and Canis familiaris in red.

pared with this gene cluster in other mammals. BBD122 and bBD125 are each represented by two genes, which bear a closer similarity to each other than to any other defensin in the bovine genome.

Early studies localized the expression of human $\beta$-defensins in this cluster to the testis, prostate $(46,162)$, as well as sertoli and seminal vesicle epithelial cells in primates (8). Subsequent cross-species analysis found predominant expression of these $\beta$-defensins in reproductive tissues of rodents $(28,68)$ and also demonstrated antimicrobial activity of human seminal plasma extracts. These $\beta$-defensins have since become known as HDPs of the male reproductive tract (50). Expression of the bovine orthologs of these genes was localized to the reproductive tract of healthy bulls, indicating constitutive expression in the absence of infection (97), although earlier in vitro assays showed significant antimicrobial activity of bBD123 against a range of bacterial species (29). A recent study of $\beta$-defensin gene expression in the pig has confirmed the expression profile detected earlier in cattle, showing predominant but not exclusive expression of the porcine homologs in mature as well as 2 wk old pig testis (27).

A potent reproductive role has been demonstrated for hBD126, a human ortholog in this gene cluster (138). Macaque sperm have been shown to be coated with $\beta$-defensin 126 (formerly ESP13.2) (141, 158), which confers a negative charge to the sperm so that the mutual repulsion between the negative charge of hBD126-coated sperm and the negatively charged cervical mucus enables sperm transmigration (140). Recent work has also shown that glycosylation of defensins on the sperm surface contributes to charge-mediated passage of sperm through cervical mucus (159). Macaque $\beta$-defensin 126 protects the sperm from immune recognition by the female immune system (157) and also mediates the attachment of sperm to oviductal epithelium (139). Interestingly, significantly extended $\mathrm{COOH}$-terminal amino acid tails have also been reported for some peptide members of the bovine chromosome 13 cluster (97), and a number of O-linked glycosylation sites were predicted in the tails of some $\beta$-defensins, particularly bBD125, bBD126, and bBD129. Although further experimental validation is required, this work supports a role for glycosylation mediating at least the reproductive functions of these genes in cattle.

\section{Syntenic Cluster $C$}

Cluster $C$ contains five genes, bBD114, bBD113, bBD110, bBD111, and bBD112, which span $51 \mathrm{~kb}$ on bovine chromosome 23 (Fig. 2C). While nothing is yet known about the expression or function of these genes in cattle, their human orthologs are expressed in the reproductive tract (101) and also in epithelial cells (73). Interestingly, two members of syntenic cluster C (DEFB111 and DEFB113) have recently been shown to be expressed in the epididymis of the boar (49).

\section{Syntenic Cluster D}

Syntenic cluster $D$ represents the most ancient cluster that has been conserved throughout the evolution of mammals and is orthologous to the single defensin cluster found in both 
chicken and zebra finch (146). This cluster consists of 30 $\beta$-defensin sequences in cattle spanning $1.9 \mathrm{mb}$ on chromosome 27. An orthologous relationship among bovine, human, and dog is apparent for eight of the defensin genes in this cluster (Fig. 2D). Despite overall conservation of $\beta$-defensin subgroups between the species, the bovine genome appears to encode a number of relatively recent gene duplicates compared with the human repertoire. Eleven of these genes form a specific subgroup that are not present in the human or dog genome (Fig. 3), although individual gene members have been identified in other artiodactyls including sheep (66), reindeer (UniProt Q0MR48), water buffalo (UniProt A3RJ36), and goat (UniProt QOPGY0). Members of this cluster include the widely studied genes LAP and TAP, as well as neutrophil $\beta$-defensins DEFB4A and DEFB5, which are involved in the immune response to various diseases in cattle $(23,24,26,82,134,145)$. Phylogenetic analysis shows the distinct clustering of specific $\beta$-defensin family members that are expanded in the bovine genome (Fig. 3). Results also show the potential duplication of specific bovine genes (e.g., bBD1) that are not present in other species. More complete drafts of the genome may provide additional clarity. Two distinct, nonidentical $\beta$-defensin 109like genes were identified in both the bovine genome and in clustered porcine sets (data not shown), displaying a high degree of similarity, indicating that this particular duplication is a feature of all artiodactyls rather than being bovine specific. In comparison, hBD109 in humans is represented by two identical copies on chromosome 8 as well as three pseudogenized loci (124). Interestingly, compared with related human $\beta$-defensins, $h B D 109$ has a very distinctive expression profile with high expression in diverse tissues including brain, lung, liver, kidney, and ovary (73).

The orthologous genes in this cluster in humans (chromosome 8) demonstrate extensive CNV, as discussed above. Although $\mathrm{CNV}$ in bovine $\beta$-defensin genes has not been comprehensively assessed, one recent study has found six of the bovine chromosome 27 defensins within one of the top $25 \mathrm{CNV}$ regions in the genome (12). Not only do the copy numbers of DEFB1, DEFB4A, DEFB5, LAP, TAP, and BNBD10 genes vary between the Bos indicus and B. taurus animals sampled, but variation in mean copy number is also apparent among Angus, Holstein, and Hereford breeds (12). Using next-generation sequencing, Bickhart et al. (12) have shown that on average $B$. taurus genomes contain between 13 and 16 copies of each of these genes. Interestingly, but anecdotally the number of copies of each of the six $\beta$-defensin genes was lower in the single $B$. indicus animal sequenced (range 7-11 copies) compared with the taurine cattle, potentially resulting from divergent natural selection pressures since the most recent common ancestor shared by these bovine subspecies.

\section{REGULATION OF $\beta$-DEFENSIN EXPRESSION}

Regulation of $\beta$-defensin gene expression is incompletely understood, in part because new genes have only recently been

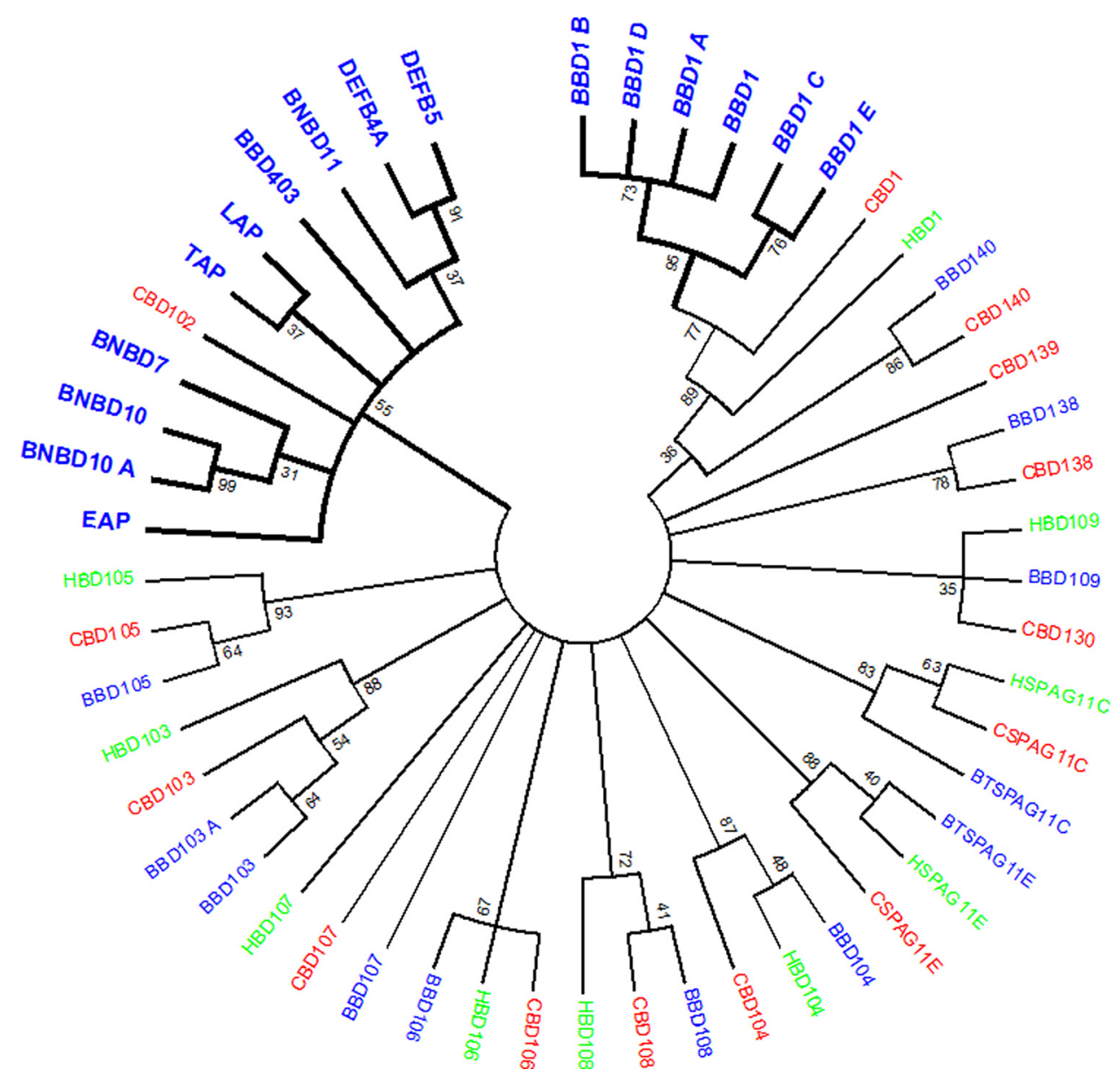

Fig. 3. Maximum likelihood derived phylogenetic tree of the bovine, human, and canine $\beta$-defensin genes mapping to bovine chromosome 27 (cluster $D$ ) showing the existence of family members expanded in the bovine genome (boldface) and also showing that copy number variants of bBD1 (boldfaced italics) are not identical. Branches with $<30 \%$ bootstrap support have been collapsed. Gene names are color coded according to species: $B$. taurus in blue, $H$. sapiens in green, and $C$. familiaris in red. 
discovered and correctly annotated in the majority of mammalian species. Produced mainly by mucosal epithelia, such as in the trachea (31) and intestine $(64,136), \beta$-defensins are also expressed in immune cells including macrophages (110) and neutrophils. Early work showed that TAP expression was dramatically increased in tracheal epithelial cells upon stimulation with bacteria or $100 \mathrm{ng} / \mathrm{ml}$ bacterial lipopolysaccharide (LPS) (32), and was NF-кB mediated. These findings are in contrast to the decreased expression of SPAG11E and eight other defensin genes in rat epididymis in response to injections of LPS in vivo (22). The differences in the responses of these defensins may result from the different models and are likely due to the significantly higher dosage of LPS used in the latter study $(50-400 \mu \mathrm{g})$. However, it is also possible that promoter regions of defensin genes from the four clusters contain diverse transcription factor binding sites and are therefore under different regulatory control. A role for the transcription factor Oct-1 in regulating TAP expression has been demonstrated in bovine mammary epithelial cells (154), while a role for NOD2 (Card15), an intracellular pattern recognition receptor, has also been established for the induction of $\mathrm{hBD} 2$ via the transcription factor NF- $\mathrm{KB}$ (144). A recent study demonstrated that bacterial-induced defensin ( $L A P, D E F B 1$, and $D E F B 4)$ expression in bovine umbilical vein endothelial cells is regulated by the autocrine production of the cytokine, tumor necrosis factor- $\alpha$ $(\mathrm{TNF}-\alpha)(4)$.

Subsets of $\beta$-defensin genes may also be developmentally regulated, as they are expressed during sexual maturation in the rat (101). Cell type-specific growth factors and androgens are known to play an important role in sperm maturation within the epididymis and may also regulate defensin expression $(74,78)$. Recent work has shown hormonal regulation of rat epididymisspecific $\beta$-defensin 15 (163). Whereas expression started at day 15 , peaked at $1 \mathrm{mo}$ and remained stable in the mature animal, DEFb15 expression was reduced in castrated animals alongside declining testosterone levels, which was rapidly rescued in response to ex vivo androgen supplementation.

Expression of defensins in macrophages can also be induced by hypoxia, as hBD2 was shown to be significantly increased at low oxygen tension in response to Mycobacterium tuberculosis (98). The transcriptional regulator hypoxia inducible factor (HIF)- $1 \alpha$ was also upregulated, which has particular relevance as HIF- $1 \alpha$-deficient mice, which fail to adapt to oxygen deprivation, are more susceptible to numerous bacterial infections (103). The recent discovery of $\beta$-defensin expression in both the testis and pituitary gland of fish (71) and in the murine brain (93) suggests other regulatory mechanisms for defensin expression have yet to be identified.

\section{ß-DEFENSIN ANTIMICROBIAL FUNCTIONS}

As small cationic peptides, $\beta$-defensins are preferentially attracted to the negatively charged phospholipids that compose bacterial membranes. The amphipathic nature of defensins allows them to insert into the phospholipid membrane of pathogens to induce membrane depolarization (111) and to destroy the integrity of the cell wall (79). Comparisons of structure and functional changes demonstrated that activity on eukaryotic cells depends on overall hydrophobicity, whereas the antimicrobial efficacy was determined by distribution of positively charged amino acids and hydrophobic side chains
(75). Recent work has also demonstrated that defensins can target prokaryotes through specific lipid receptors to block and sequester lipids and thereby inhibit cell wall biosynthesis (113, 147). As a result of these multiple antimicrobial mechanisms, defensins are known to be active against gram positive and gram negative bacteria as well as fungi and enveloped viruses (131). Functional studies have been mainly performed in vitro, which can lead to inappropriate attribution of antimicrobial function in nonphysiological conditions (122), although their salt sensitivity may be concentration dependent (130). Relevantly, defensins have been found in uncharacteristically high concentrations in porcine tongue epithelium $(20-100 \mu \mathrm{g} / \mathrm{ml})$ (128) and between 1 and $10 \mathrm{mg} / \mathrm{ml}$ in neutrophil granules (44, 81). Furthermore, some in vivo studies have verified their role in enhanced immunity during infection. Mice lacking $\beta$-defensin Defb1 have been shown to have delayed clearance of Haemophilus influenzae from the lung (94) and increased incidence of Staphylococcus species in the bladder (92). Expression of porcine $\beta$-defensin 1 (pBD1), an ortholog of human $\beta$-defensin-2, is associated with protection against respiratory disease; $500 \mu \mathrm{g}$ of $\mathrm{pBD} 1$ given at the time of challenge conferred protection against Bordetella pertussis in newborn piglets (36).

Although the antibacterial activity of many defensins is abolished at physiological concentrations of $\mathrm{NaCl}(150 \mathrm{mM})$ (95), low sodium concentrations are found in rat epididymis (58 $\mathrm{mM}$ in caput to $15 \mathrm{mM}$ in cauda), indicating that they may also play a protective role in the reproductive tract (143). Furthermore, neutrophil elastase in semen is thought to activate defensins, and the titer of this enzyme increases during inflammation in the male reproductive tract $(164,165)$. When tested in vitro, $\beta$-defensins have shown efficacy against a broad range of pathogens that can invade the reproductive tract [including methicillin-resistant Staphylococcus aureus (MRSA) and Escherichia coli] at concentrations ranging from 10 to $50 \mu \mathrm{g} / \mathrm{ml}(52$, $115,116)$. E. coli is a major cause of postpartum reproductive failure in cattle $(126,127)$, and bBD123, a novel bovine defensin, has shown very high efficacy against $E$. coli at a concentration range of $0.9 \mu \mathrm{g} / \mathrm{ml}$ in vitro (29).

\section{$\beta$-DEFENSIN IMMUNOMODULATORY FUNCTIONS}

It is now well established that innate antimicrobial peptides, including defensins, have immunological roles in addition to their direct antimicrobial ones and emerging studies show that $\beta$-defensins can link the innate and adaptive arms of the immune response. Human $\beta$-defensin-3 (hBD3), for example, can induce expression of the costimulatory molecules CD80, CD86, and CD40 on monocytes and myeloid dendritic cells in a Toll-like receptor (TLR)-dependent manner. In studies with HEK cells engineered to express various TLRs, it was shown that activation of NF- $\mathrm{KB}$ by hBD3 depends on the expression of both TLR1 and TLR2 (42). Thus, TLR signaling is not restricted to recognition of microbial patterns but also can be initiated by host-derived defensin peptides (13). Recent work has shown that hBD3 can rapidly enter TLR4-stimulated macrophages to dampen the expression of proinflammatory genes (125). The cross talk between the immune and reproductive systems provided by endogenous HDP expression may play important functional roles in dampening the immune response 
to foreign antigen such as sperm but also in regulating immune tolerance of an allogenic fetus during pregnancy (3).

At lower concentrations of $0.1-1 \mu \mathrm{g} / \mathrm{ml}$, the primary role of $\beta$-defensins may be to induce chemotaxis of immune cells to the site of infection (153). Striking similarities are emerging between defensins and traditional chemokines, including size, disulfide bonding, and cationic charge (35), which potentially account for the ability of defensins to recruit innate as well as adaptive immune cells. HBD2 and HBD3 has been shown to be chemotactic for a broad spectrum of leukocytes including neutrophils (99), CD4 memory T cells, macrophages (70), and immature dendritic cells (149). Their role as chemoattractants is mediated via both CCR2 and CCR6 receptors $(108,152)$. The upregulation of costimulatory molecules and dendritic cell maturation drive a robust Th1 type immune response, and so these molecules may also play additional important roles in the activation as well as regulation of an immune response to infection.

\section{$\beta$-DEFENSINS AND IMPROVED ANIMAL HEALTH}

Developments in molecular biological tools, including nextgeneration sequencing, are helping identify new clusters of $\beta$-defensin genes across genomes of farm animal species and annotate the specific genes that vary in copy number among breeds and individuals. They also offer an unprecedented window into understanding $\beta$-defensin gene expression and regulation across multiple tissues. Targeting regulation of $\beta$-defensin expression and function during diverse physiological events could have a significant impact on bovine health and reproduction (Fig. 4).

\section{Alternatives to Antibiotics}

Despite millions of years of exposure, microbes have not developed resistance against antimicrobial peptides, perhaps because they target components that are integral to bacterial structures (77). Native $\beta$-defensins are effective against many pathogenic agents both in vitro and in vivo $(36,92,94)$. Modification of the $\beta$-defensin structure-function relationship through targeted residue substitution (39) can generate peptides with additional immunomodulatory as well as enhanced antimicrobial efficacy (156). Often based on information garnered from positive selection studies $(57,86,149)$, these strategies offer an opportunity to overcome problems associated with emerging antibiotic resistant bacterial strains. A recent study has shown that cattle are a reservoir for the emergence of human-pathogenic MRSA (132). In this regard, it is of interest that increasing the hydrophobicity of a bovine $\beta$-defensin 123-derived peptide had increased efficacy against MRSA with a $50 \%$ lethal dose of $3.91 \mu \mathrm{g} / \mathrm{ml}$ in vitro (86). Human $\alpha$-defensins are also effective against trypansomes $(72,85)$, and therefore bovine $\beta$-defensins could provide novel trypanocidal treatments or breeding targets for one of the most important zoonotic pathogens in the developing world. Murine $\beta$-defensin-3 has also shown to have potent antiviral effects against influenza virus, both in vitro and in vivo (69). The role of bovine $\beta$-defensin orthologs in resisting viral infections in cattle has not been investigated but may hold significant promise. It is also possible that the novel AMPs discovered as new genomes are completed may be useful to treat diseases in other species (48) and to meet emerging pathogenic challenges now and into the future (142).

\section{Vaccine Adjuvants}

$\beta$-Defensins may prove useful as broad-spectrum adjuvants, which are required for improved vaccine design in cattle (1). Artificial induction of $\beta$-defensin-2 (mBD2) contributes to improved control $M$. tuberculosis infection in mice (107). It is suggested that $\beta$-defensin expression contributes to the establishment of a beneficial Th1 response via dendritic cell activation and increased expression of cytokines such as IFN- $\gamma$, IL-12, and IL-6 $(13,106)$. Additionally, defensins facilitate the

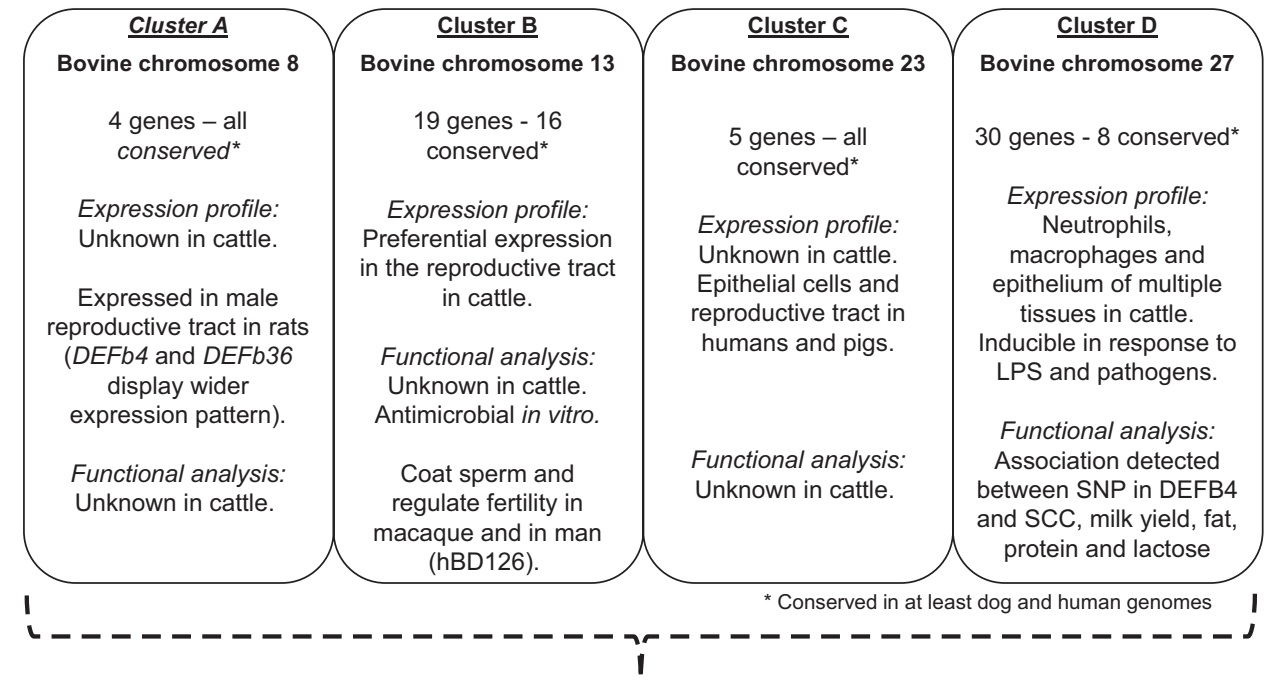

Potential Research Applications

- Alternative to antibiotics

- Adjuvants for improved vaccine design

- Dietary manipulation of $\beta$-defensin expression levels

- Breeding targets for higher fertility and disease resistance
Fig. 4. Sequencing and annotation of multiple genomes across many species are facilitating a comparative immunology discovery and characterization of $\beta$-defensin gene repertoire within the bovine genome. Functional characterization has identified important roles for genes in 2 of the 4 clusters in reproduction and immunology. Important potential future research applications of these genes are also identified. 
efficient delivery of bound antigen to antigen presenting cells (76). In vivo murine models have shown that mBD2 promotes antitumor NK and beneficial T cell responses (89).

\section{Dietary Manipulation of Defensin Levels in Cattle}

Controlled induction of these natural antibiotics to protect against infections $(51,161)$ could hold significant promise for reducing the burden of infectious disease in livestock. Interestingly, upregulation of hBD1 and hBD2 by epithelial cells in response to short-chain fatty acids including acetate, propionate, and butyrate has recently been documented (11). In chickens, dietary supplementation with $0.1 \%$ butyrate led to a significant increase in defensin gene expression in the caecum and a concurrent 10-fold reduction in the Salmonella enteritidis titer (133). As these short chain fatty acids (including butyrate) are also by-products of ruminal digestion, this finding suggest that dietary supplementation may enhance immunity in cattle.

\section{Targets for Improved Cattle Breeding}

The observed gene duplication within the bovine $\beta$-defensin cluster has created a repertoire of phylogenetically diverse functional genes, which is substantially larger than that described for humans and mice. Single nucleotide polymorphisms (SNPs) in $\beta$-defensin genes have been advocated as potential markers for selection of avian resistance to Salmonella infection (55). A SNP in the bovine bBD103 gene (contained within the CNV region on chromosome 27) is associated with red coat color in cattle (34). The canine ortholog (cBD103) also binds with high affinity to a melanocortin receptor, which regulates pigment type-switching in dogs and in wolves $(5,21)$. While coat color may not be a breeding priority in cattle, SNPs and CNV in $\beta$-defensin genes involved in the innate immune response could be valuable for selecting animals with superior disease resistance. In humans, defensin gene CNV has been associated with differing susceptibility to Crohn's disease as well as psoriasis $(59,62)$. Although data in cattle are limited, upward of 13 gene copies are seen for some immune genes in various cattle breeds sequenced, including, for LAP, TAP, and DEFB5, genes that have been previously shown to be upregulated in response to infection, particularly in mammary, lung, and uterine tissues $(23,25,30,47,82,114,134)$. In terms of production traits, $\beta$-defensin genotypes are also associated with reduced somatic cell count (SCC) in the Jersey breed of cattle (148). Studies in Holstein-Friesians supported this finding as polymorphisms in DEFB4A were associated with milk constituents (fat, protein, and lactose) as well as SCC (6).

In regard to the bovine chromosome 13 defensins, there is considerable evidence now that the orthologs of these genes regulate fertility in other species, including humans (139, 140, 157). Importantly a polymorphism found in the human $\beta$-defensin 126 gene has been correlated with lower fertility in a human cohort. Sperm from homozygous men exhibit lower levels of glycosylation and an $84 \%$ reduction in the rate of penetration of a hyaluronic acid gel, a surrogate for cervical mucus, compared with the other genotypes (138). In cattle, population genetic analysis showed significant SNP frequency differences in $\beta$-defensin genes 115, 117, 121, and 122 between Holstein-Friesian and the higher-fertility Norwegian Red breed (97). Combined with the corresponding expression of these genes in reproductive tissues in this study, this suggests a potential role for these genes in the regulation of bovine fertility (96).

\section{CONCLUSION}

The gene content and organization of the bovine $\beta$-defensin loci are broadly similar to that of humans and mice; however, multiple duplication events have led to a marked expansion in the number of the chromosome $27 \beta$-defensin genes of the $B$. taurus genome. This cluster shows remarkable CNV with recent analyses with upward of 25 individual gene copies in some bovine genomes sequenced, as well as marked interanimal variation in gene number (12). Strong evolutionary pressures in this lineage have selected for the development of enlarged sets of multifunctional $\beta$-defensin genes. Because key roles are emerging for these genes in reproduction and immunity, genetic variation within these genes hold exciting potential for improved cattle breeding to improve bovine health and fertility.

\section{ACKNOWLEDGMENTS}

The authors would like to thank two anonymous reviewers for helpful comment and insight.

\section{GRANTS}

This study was supported by the Research Stimulus Fund of the Irish Department of Agriculture, Food and the Marine (RSF/06340) and (11/S/104) to C. O'Farrelly and K. G. Meade.

\section{DISCLOSURES}

No conflicts of interest, financial or otherwise, are declared by the author(s).

\section{AUTHOR CONTRIBUTIONS}

Author contributions: K.G.M., P.C., and C.O. conception and design of research; K.G.M., P.C., F.N., A.T.L., and C.O. interpreted results of experiments; K.G.M. drafted manuscript; K.G.M., P.C., A.T.L., and C.O. edited and revised manuscript; K.G.M. and C.O. approved final version of manuscript; F.N. prepared figures.

\section{REFERENCES}

1. Adams LG, Khare S, Lawhon SD, Rossetti CA, Lewin HA, Lipton MS, Turse JE, Wylie DC, Bai Y, Drake KL. Enhancing the role of veterinary vaccines reducing zoonotic diseases of humans: linking systems biology with vaccine development. Vaccine 29: 7197-7206, 2011.

2. Allaker RP. Host defence peptides-a bridge between the innate and adaptive immune responses. Trans R Soc Trop Med Hyg 102: 3-4, 2008.

3. Aloe S, Weber F, Behr B, Sauter-Louis C, Zerbe H. Modulatory effects of bovine seminal plasma on uterine inflammatory processes. Reprod Domest Anim 47: 12-19, 2012.

4. Alva-Murillo N, Tellez-Perez AD, Sagrero-Cisneros E, Lopez-Meza JE, Ochoa-Zarzosa A. Expression of antimicrobial peptides by bovine endothelial cells. Cell Immunol 280: 108-112, 2012.

5. Anderson TM, vonHoldt BM, Candille SI, Musiani M, Greco C, Stahler DR, Smith DW, Padhukasahasram B, Randi E, Leonard JA, Bustamante CD, Ostrander EA, Tang H, Wayne RK, Barsh GS. Molecular and evolutionary history of melanism in North American gray wolves. Science 323: 1339-1343, 2009.

6. Bagnicka E, Strzalkowska N, Flisikowski K, Szreder T, Jozwik A, Prusak B, Krzyzewski J, Zwierzchowski L. The polymorphism in the beta4-defensin gene and its association with production and somatic cell count in Holstein-Friesian cows. J Anim Breed Genet 124: 150-156, 2007.

7. Baldwin RL 6th, Wu S, Li W, Li C, Bequette BJ, Li RW. Quantification of transcriptome responses of the rumen epithelium to butyrate infusion using RNA-seq technology. Gene Regul Syst Bio 6: 67-80, 2012.

8. Bals R, Lang C, Weiner DJ, Vogelmeier C, Welsch U, Wilson JM. Rhesus monkey (Macaca mulatta) mucosal antimicrobial peptides are close homologues of human molecules. Clin Diagn Lab Immunol 8: $370-375,2001$. 
9. Bauer F, Schweimer K, Kluver E, Conejo-Garcia JR, Forssmann WG, Rosch P, Adermann K, Sticht H. Structure determination of human and murine beta-defensins reveals structural conservation in the absence of significant sequence similarity. Prot Sci 10: 2470-2479, 2001.

10. Belov K, Sanderson CE, Deakin JE, Wong ES, Assange D, McColl KA, Gout A, de Bono B, Barrow AD, Speed TP, Trowsdale J, Papenfuss AT. Characterization of the opossum immune genome provides insights into the evolution of the mammalian immune system. Genome Res 17: 982-991, 2007.

11. Bentley-Hewitt KL, Blatchford PA, Parkar SG, Ansell J, Pernthaner A. Digested and fermented green kiwifruit increases human beta-defensin 1 and 2 production in vitro. Plant Foods Hum Nutr 67: 208-214, 2012.

12. Bickhart DM, Hou Y, Schroeder SG, Alkan C, Cardone MF, Matukumalli LK, Song J, Schnabel RD, Ventura M, Taylor JF, Garcia JF, Van Tassell CP, Sonstegard TS, Eichler EE, Liu GE. Copy number variation of individual cattle genomes using next-generation sequencing. Genome Res 22: 778-790, 2012.

13. Biragyn A, Ruffini PA, Leifer CA, Klyushnenkova E, Shakhov A, Chertov O, Shirakawa AK, Farber JM, Segal DM, Oppenheim JJ, Kwak LW. Toll-like receptor 4-dependent activation of dendritic cells by beta-defensin 2. Science 298: 1025-1029, 2002.

14. Boniotto M, Tossi A, DelPero M, Sgubin S, Antcheva N, Santon D, Masters J, Crovella S. Evolution of the beta defensin 2 gene in primates. Genes Immun 4: 251-257, 2003.

15. Bowdish DM, Davidson DJ, Hancock RE. A re-evaluation of the role of host defence peptides in mammalian immunity. Curr Protein Pept Sci 6: $35-51,2005$.

16. Bowdish DM, Davidson DJ, Scott MG, Hancock RE. Immunomodulatory activities of small host defense peptides. Antimicrob Agents Chemother 49: 1727-1732, 2005.

17. Brogden KA, Ackermann M, McCray PB Jr, Tack BF. Antimicrobial peptides in animals and their role in host defences. Int $J$ Antimicrob Agents 22: 465-478, 2003.

18. Bruhn O, Paul S, Tetens J, Thaller G. The repertoire of equine intestinal alpha-defensins. BMC Genom 10: 631, 2009.

19. Bruhn O, Regenhard P, Michalek M, Paul S, Gelhaus C, Jung S, Thaller G, Podschun R, Leippe M, Grotzinger J, Kalm E. A novel horse alpha-defensin: gene transcription, recombinant expression and characterization of the structure and function. Biochem J 407: 267-276, 2007.

20. Campopiano DJ, Clarke DJ, Polfer NC, Barran PE, Langley RJ, Govan JR, Maxwell A, Dorin JR. Structure-activity relationships in defensin dimers: a novel link between beta-defensin tertiary structure and antimicrobial activity. J Biol Chem 279: 48671-48679, 2004.

21. Candille SI, Kaelin CB, Cattanach BM, Yu B, Thompson DA, Nix MA, Kerns JA, Schmutz SM, Millhauser GL, Barsh GS. A -defensin mutation causes black coat color in domestic dogs. Science 318: $1418-$ 1423,2007

22. Cao D, Li Y, Yang R, Wang Y, Zhou Y, Diao H, Zhao Y, Zhang Y, Lu J. Lipopolysaccharide-induced epididymitis disrupts epididymal beta-defensin expression and inhibits sperm motility in rats. Biol Reprod 83: 1064-1070, 2010.

23. Caverly JM, Diamond G, Gallup JM, Brogden KA, Dixon RA, Ackermann MR. Coordinated expression of tracheal antimicrobial peptide and inflammatory-response elements in the lungs of neonatal calves with acute bacterial pneumonia. Infect Immun 71: 2950-2955, 2003.

24. Chapwanya A, Meade KG, Doherty ML, Callanan JJ, Mee JF, O'Farrelly C. Histopathological and molecular evaluation of HolsteinFriesian cows postpartum: toward an improved understanding of uterine innate immunity. Theriogenology 71: 1396-1407, 2009.

25. Chapwanya A, Meade KG, Doherty ML, Callanan JJ, O'Farrelly C. Endometrial epithelial cells are potent producers of tracheal antimicrobial peptide and serum amyloid A3 gene expression in response to E. coli stimulation. Vet Immunol Immunopathol 151: 157-162, 2013.

26. Chapwanya A, Meade KG, Foley C, Narciandi F, Evans AC, Doherty ML, Callanan JJ, O'Farrelly C. The postpartum endometrial inflammatory response: a normal physiological event with potential implications for bovine fertility. J Reprod Fertil Dev 24: 1028-1039, 2012.

27. Choi MK, Le MT, Nguyen DT, Choi H, Kim W, Kim JH, Chun J, Hyeon J, Seo K, Park C. Genome-level identification, gene expression, and comparative analysis of porcine ss-defensin genes. BMC Genet 13: 98, 2012.
28. Com E, Bourgeon F, Evrard B, Ganz T, Colleu D, Jegou B, Pineau C. Expression of antimicrobial defensins in the male reproductive tract of rats, mice, and humans. Biol Reprod 68: 95-104, 2003.

29. Cormican P, Meade KG, Cahalane S, Narciandi F, Chapwanya A, Lloyd AT, O'Farrelly C. Evolution, expression and effectiveness in a cluster of novel bovine beta-defensins. Immunogenetics 60: 147-156, 2008.

30. Davies D, Meade KG, Herath S, Eckersall PD, Gonzalez D, White JO, Conlan RS, O'Farrelly C, Sheldon IM. Toll-like receptor and antimicrobial peptide expression in the bovine endometrium. Reprod Biol Endocrinol 6: 53, 2008.

31. Diamond G, Jones DE, Bevins CL. Airway epithelial cells are the site of expression of a mammalian antimicrobial peptide gene. Proc Natl Acad Sci USA 90: 4596-4600, 1993.

32. Diamond G, Kaiser V, Rhodes J, Russell JP, Bevins CL. Transcriptional regulation of beta-defensin gene expression in tracheal epithelial cells. Infect Immun 68: 113-119, 2000.

33. Diamond G, Zasloff M, Eck H, Brasseur M, Maloy WL, Bevins CL. Tracheal antimicrobial peptide, a cysteine-rich peptide from mammalian tracheal mucosa: peptide isolation and cloning of a cDNA. Proc Natl Acad Sci USA 88: 3952-3956, 1991.

34. Dreger DL, Schmutz SM. The variant red coat colour phenotype of Holstein cattle maps to BTA27. Anim Genet 41: 109-112, 2010.

35. Durr M, Peschel A. Chemokines meet defensins: the merging concepts of chemoattractants and antimicrobial peptides in host defense. Infect Immun 70: 6515-6517, 2002.

36. Elahi S, Buchanan RM, Attah-Poku S, Townsend HG, Babiuk LA, Gerdts V. The host defense peptide beta-defensin 1 confers protection against Bordetella pertussis in newborn piglets. Infect Immun 74: 2338 2352, 2006

37. Elsbach P. What is the real role of antimicrobial polypeptides that can mediate several other inflammatory responses? J Clin Invest 111: 1643$1645,2003$.

38. Elsik CG, Tellam RL, Worley KC, Gibbs RA, Muzny DM, Weinstock GM, Adelson DL, Eichler EE, Elnitski L, Guigo R, Hamernik DL, Kappes SM, Lewin HA, Lynn DJ, Nicholas FW, Reymond A, Rijnkels M, Skow LC, Zdobnov EM, Schook L, Womack J, Alioto T, Antonarakis SE, Astashyn A, Chapple CE, Chen HC, Chrast J, Camara F, Ermolaeva O, Henrichsen CN, Hlavina W, Kapustin Y, Kiryutin B, Kitts P, Kokocinski F, Landrum M, Maglott D, Pruitt K, Sapojnikov V, Searle SM, Solovyev V, Souvorov A, Ucla C, Wyss C, Anzola JM, Gerlach D, Elhaik E, Graur D, Reese JT, Edgar RC, McEwan JC, Payne GM, Raison JM, Junier T, Kriventseva EV, Eyras E, Plass M, Donthu R, Larkin DM, Reecy J, Yang MQ, Chen L, Cheng Z, Chitko-McKown CG, Liu GE, Matukumalli LK, Song J, Zhu B, Bradley DG, Brinkman FS, Lau LP, Whiteside MD, Walker A, Wheeler TT, Casey T, German JB, Lemay DG, Maqbool NJ, Molenaar AJ, Seo S, Stothard P, Baldwin CL, Baxter R, Brinkmeyer-Langford CL, Brown WC, Childers CP, Connelley T, Ellis SA, Fritz K, Glass EJ, Herzig CT, Iivanainen A, Lahmers KK, Bennett AK, Dickens CM, Gilbert JG, Hagen DE, Salih H, Aerts J, Caetano AR, Dalrymple B, Garcia JF, Gill CA, Hiendleder SG, Memili E, Spurlock D, Williams JL, Alexander L, Brownstein MJ, Guan L, Holt RA, Jones SJ, Marra MA, Moore R, Moore SS, Roberts A, Taniguchi M, Waterman RC, Chacko J, Chandrabose MM, Cree A, Dao MD, Dinh HH, Gabisi RA, Hines S, Hume J, Jhangiani SN, Joshi V, Kovar CL, Lewis LR, Liu YS, Lopez J, Morgan MB, Nguyen NB, Okwuonu GO, Ruiz SJ, Santibanez J, Wright RA, Buhay C, Ding Y, Dugan-Rocha S, Herdandez J, Holder M, Sabo A, Egan A, Goodell J, Wilczek-Boney K, Fowler GR, Hitchens ME, Lozado RJ, Moen C, Steffen D, Warren JT, Zhang J, Chiu R, Schein JE, Durbin KJ, Havlak P, Jiang H, Liu Y, Qin X, Ren Y, Shen Y, Song H, Bell SN, Davis C, Johnson AJ, Lee S, Nazareth LV, Patel BM, Pu LL, Vattathil S, Williams RL Jr, Curry S, Hamilton C, Sodergren E, Wheeler DA, Barris W, Bennett GL, Eggen A, Green RD, Harhay GP, Hobbs M, Jann O, Keele JW, Kent MP, Lien S, McKay SD, McWilliam S, Ratnakumar A, Schnabel RD, Smith T, Snelling WM, Sonstegard TS, Stone RT, Sugimoto Y, Takasuga A, Taylor JF, Van Tassell CP, Macneil MD, Abatepaulo AR, Abbey CA, Ahola V, Almeida IG, Amadio AF, Anatriello E, Bahadue SM, Biase FHBoldt CR, Carroll JA, Carvalho WA, Cervelatti EP, Chacko E, Chapin JE, Cheng Y, Choi J, Colley AJ, de Campos TA, De Donato M, Santos IK, de Oliveira CJ, Deobald H, Devinoy E, Donohue KE, Dove P, Eberlein A, Fitzsimmons CJ, 
Franzin AM, Garcia GR, Genini S, Gladney CJ, Grant JR, Greaser ML, Green JA, Hadsell DL, Hakimov HA, Halgren R, Harrow JL, Hart EA, Hastings N, Hernandez M, Hu ZL, Ingham A, Iso-Touru T, Jamis C, Jensen K, Kapetis D, Kerr T, Khalil SS, Khatib H, Kolbehdari D, Kumar CG, Kumar D, Leach R, Lee JC, Li C, Logan KM, Malinverni R, Marques E, Martin WF, Martins NF, Maruyama SR, Mazza R, McLean KL, Medrano JF, Moreno BT, More DD, Muntean CT, Nandakumar HP, Nogueira MF, Olsaker I, Pant SD, Panzitta F, Pastor RC, Poli MA, Poslusny N, Rachagani S, Ranganathan S, Razpet A, Riggs PK, Rincon G, Rodriguez-Osorio N, Rodriguez-Zas SL, Romero NE, Rosenwald A, Sando L, Schmutz SM, Shen L, Sherman L, Southey BR, Lutzow YS, Sweedler JV, Tammen I, Telugu BP, Urbanski JM, Utsunomiya YT, Verschoor CP, Waardenberg AJ, Wang Z, Ward R, Weikard R, Welsh TH, Jr., White SN, Wilming LG, Wunderlich KR, Yang J, Zhao FQ. The genome sequence of taurine cattle: a window to ruminant biology and evolution. Science 324: 522-528, 2009.

39. Fjell CD, Hiss JA, Hancock RE, Schneider G. Designing antimicrobial peptides: form follows function. Nat Rev Drug Discov 11: 37-51, 2012.

40. Fjell CD, Jenssen H, Fries P, Aich P, Griebel P, Hilpert K, Hancock RE, Cherkasov A. Identification of novel host defense peptides and the absence of alpha-defensins in the bovine genome. Proteins 73: 420-430, 2008.

41. Fouts DE, Szpakowski S, Purushe J, Torralba M, Waterman RC, MacNeil MD, Alexander LJ, Nelson KE. Next generation sequencing to define prokaryotic and fungal diversity in the bovine rumen. PLoS One 7: e48289, 2012.

42. Funderburg N, Lederman MM, Feng Z, Drage MG, Jadlowsky J, Harding CV, Weinberg A, Sieg SF. Human-defensin-3 activates professional antigen-presenting cells via Toll-like receptors 1 and 2. Proc Natl Acad Sci USA 104: 18631-18635, 2007.

43. Ganz T. Defensins: antimicrobial peptides of innate immunity. Nat Rev Immunol 3: 710-720, 2003.

44. Ganz T. Extracellular release of antimicrobial defensins by human polymorphonuclear leukocytes. Infect Immun 55: 568-571, 1987.

45. Ganz T, Selsted ME, Szklarek D, Harwig SS, Daher K, Bainton DF, Lehrer RI. Defensins. Natural peptide antibiotics of human neutrophils. J Clin Invest 76: 1427-1435, 1985.

46. Garcia JR, Krause A, Schulz S, Rodriguez-Jimenez FJ, Kluver E, Adermann K, Forssmann U, Frimpong-Boateng A, Bals R, Forssmann WG. Human beta-defensin 4: a novel inducible peptide with a specific salt-sensitive spectrum of antimicrobial activity. FASEB $J 15$ : 1819-1821, 2001.

47. Goldammer T, Zerbe H, Molenaar A, Schuberth HJ, Brunner RM, Kata SR, Seyfert HM. Mastitis increases mammary mRNA abundance of beta-defensin 5, toll-like-receptor 2 (TLR2), and TLR4 but not TLR9 in cattle. Clin Diagn Lab Immunol 11: 174-185, 2004.

48. Groenink J, Walgreen-Weterings E, van't Hof W, Veerman EC, Nieuw Amerongen AV. Cationic amphipathic peptides, derived from bovine and human lactoferrins, with antimicrobial activity against oral pathogens. FEMS Microbiol Lett 179: 217-222, 1999.

49. Guyonnet B, Marot G, Dacheux JL, Mercat MJ, Schwob S, Jaffrezic F, Gatti JL. The adult boar testicular and epididymal transcriptomes. BMC Genom 10: 369, 2009.

50. Hall SH, Hamil KG, French FS. Host defense proteins of the male reproductive tract. J Androl 23: 585-597, 2002.

51. Hancock RE, Nijnik A, Philpott DJ. Modulating immunity as a therapy for bacterial infections. Nat Rev Microbiol 10: 243-254, 2012.

52. Harder J, Bartels J, Christophers E, Schroder JM. Isolation and characterization of human beta -defensin-3, a novel human inducible peptide antibiotic. J Biol Chem 276: 5707-5713, 2001.

53. Hardwick RJ, Amogne W, Mugusi S, Yimer G, Ngaimisi E, Habtewold A, Minzi O, Makonnen E, Janabi M, Machado LR, Viskaduraki M, Mugusi F, Aderaye G, Lindquist L, Hollox EJ, Aklillu E. beta-Defensin genomic copy number is associated with HIV load and immune reconstitution in Sub-Saharan Africans. J Infect Dis 206: 1012_ 1019, 2012.

54. Hardwick RJ, Machado LR, Zuccherato LW, Antolinos S, Xue Y, Shawa N, Gilman RH, Cabrera L, Berg DE, Tyler-Smith C, Kelly P, Tarazona-Santos E, Hollox EJ. A worldwide analysis of beta-defensin copy number variation suggests recent selection of a high-expressing DEFB103 gene copy in East Asia. Hum Mutat 32: 743-750, 2011.
55. Hasenstein JR, Lamont SJ. Chicken gallinacin gene cluster associated with Salmonella response in advanced intercross line. Avian Dis 51: 561-567, 2007.

56. Hellgren O, Ekblom R. Evolution of a cluster of innate immune genes (beta-defensins) along the ancestral lines of chicken and zebra finch. Immunome Res 6: 3, 2010.

57. Higgs R, Lynn DJ, Cahalane S, Alana I, Hewage CM, James T, Lloyd AT, O'Farrelly C. Modification of chicken avian beta-defensin- 8 at positively selected amino acid sites enhances specific antimicrobial activity. Immunogenetics 59: 573-580, 2007.

58. Hollox EJ. Beta-defensins and Crohn's disease: confusion from counting copies. Am J Gastroenterol 105: 360-362, 2010.

59. Hollox EJ. Copy number variation of beta-defensins and relevance to disease. Cytogenet Genome Res 123: 148-155, 2008.

60. Hollox EJ, Armour JA. Directional and balancing selection in human beta-defensins. BMC Evol Biol 8: 113, 2008.

61. Hollox EJ, Armour JA, Barber JC. Extensive normal copy number variation of a beta-defensin antimicrobial-gene cluster. Am J Hum Genet 73: 591-600, 2003.

62. Hollox EJ, Huffmeier U, Zeeuwen PL, Palla R, Lascorz J, RodijkOlthuis D, van de Kerkhof PC, Traupe H, de Jongh G, den Heijer M, Reis A, Armour JA, Schalkwijk J. Psoriasis is associated with increased beta-defensin genomic copy number. Nat Genet 40: 23-25, 2008.

63. Hoover DM, Rajashankar KR, Blumenthal R, Puri A, Oppenheim JJ, Chertov O, Lubkowski J. The structure of human beta-defensin-2 shows evidence of higher order oligomerization. J Biol Chem 275: 32911-32918, 2000.

64. Huttner KM, Brezinski-Caliguri DJ, Mahoney MM, Diamond G. Antimicrobial peptide expression is developmentally regulated in the ovine gastrointestinal tract. J Nutr 128: 297S-299S, 1998.

66. Huttner KM, Lambeth MR, Burkin HR, Burkin DJ, Broad TE. Localization and genomic organization of sheep antimicrobial peptide genes. Gene 206: 85-91, 1998.

67. Isobe N, Nakamura J, Nakano H, Yoshimura Y. Existence of functional lingual antimicrobial peptide in bovine milk. J Dairy Sci 92: 2691-2695, 2009.

68. Jelinsky SA, Turner TT, Bang HJ, Finger JN, Solarz MK, Wilson E, Brown EL, Kopf GS, Johnston DS. The rat epididymal transcriptome: comparison of segmental gene expression in the rat and mouse epididymides. Biol Reprod 76: 561-570, 2007.

69. Jiang Y, Yang D, Li W, Wang B, Jiang Z, Li M. Antiviral activity of recombinant mouse beta-defensin 3 against influenza A virus in vitro and in vivo. Antivir Chem Chemother 22: 255-262, 2012.

70. Jin G, Kawsar HI, Hirsch SA, Zeng C, Jia X, Feng Z, Ghosh SK, Zheng QY, Zhou A, McIntyre TM, Weinberg A. An antimicrobial peptide regulates tumor-associated macrophage trafficking via the chemokine receptor CCR2, a model for tumorigenesis. PLoS One 5: e10993, 2010.

71. Jin JY, Zhou L, Wang Y, Li Z, Zhao JG, Zhang QY, Gui JF. Antibacterial and antiviral roles of a fish beta-defensin expressed both in pituitary and testis. PLoS One 5: e12883, 2010.

72. Johnson CA, Rachakonda G, Kleshchenko YY, Nde PN, Madison MN, Pratap S, Cardenas TC, Taylor C, Lima MF, Villalta F. Cellular response to Trypanosoma cruzi infection induces secretion of defensin $\alpha-1$, which damages the flagellum, neutralizes trypanosome motility, and inhibits infection. Infect Immun 81: 4139-4148, 2013.

73. Kao CY, Chen Y, Zhao YH, Wu R. ORFeome-based search of airway epithelial cell-specific novel human beta-defensin genes. Am J Respir Cell Mol Biol 29: 71-80, 2003.

74. Kirby JL, Yang L, Labus JC, Hinton BT. Characterization of fibroblast growth factor receptors expressed in principal cells in the initial segment of the rat epididymis. Biol Reprod 68: 2314-2321, 2003.

75. Kluver E, Schulz-Maronde S, Scheid S, Meyer B, Forssmann WG, Adermann K. Structure-activity relation of human beta-defensin 3: influence of disulfide bonds and cysteine substitution on antimicrobial activity and cytotoxicity. Biochemistry (Mosc) 44: 9804-9816, 2005.

76. Kohlgraf KG, Pingel LC, Dietrich DE, Brogden KA. Defensins as anti-inflammatory compounds and mucosal adjuvants. Future Microbiol 5: 99-113, 2010.

77. Lai Y, Gallo RL. AMPed up immunity: how antimicrobial peptides have multiple roles in immune defense. Trends Immunol 30: 131-141, 2009.

78. Lan ZJ, Labus JC, Hinton BT. Regulation of gamma-glutamyl transpeptidase catalytic activity and protein level in the initial segment of the 
rat epididymis by testicular factors: role of basic fibroblast growth factor. Biol Reprod 58: 197-206, 1998.

79. Lehrer RI. Primate defensins. Nat Rev Microbiol 2: 727-738, 2004.

80. Lehrer RI, Ganz T. Defensins of vertebrate animals. Curr Opin Iтmunol 14: 96-102, 2002.

81. Lehrer RI, Lichtenstein AK, Ganz T. Defensins: antimicrobial and cytotoxic peptides of mammalian cells. Аппи Rev Immunol 11: 105-128, 1993.

82. Lopez-Meza JE, Gutierrez-Barroso A, Ochoa-Zarzosa A. Expression of tracheal antimicrobial peptide in bovine mammary epithelial cells. Res Vet Sci 87: 59-63, 2009.

83. Lynn DJ, Bradley DG. Discovery of alpha-defensins in basal mammals. Dev Comp Immunol 31: 963-967, 2007.

84. Lynn DJ, Higgs R, Gaines S, Tierney J, James T, Lloyd AT, Fares MA, Mulcahy G, O'Farrelly C. Bioinformatic discovery and initial characterisation of nine novel antimicrobial peptide genes in the chicken. Immunogenetics 56: 170-177, 2004.

85. Madison MN, Kleshchenko YY, Nde PN, Simmons KJ, Lima MF, Villalta F. Human defensin alpha-1 causes Trypanosoma cruzi membrane pore formation and induces DNA fragmentation, which leads to trypanosome destruction. Infect Immun 75: 4780-4791, 2007.

86. Meade KG, Cahalane S, Narciandi F, Cormican P, Lloyd AT, O'Farrelly C. Directed alteration of a novel bovine beta-defensin to improve antimicrobial efficacy against methicillin-resistant Staphylococcus aureus (MRSA). Int J Antimicrob Agents 32: 392-397, 2008.

87. Meade KG, Higgs R, Lloyd AT, Giles S, O'Farrelly C. Differential antimicrobial peptide gene expression patterns during early chicken embryological development. Dev Comp Immunol 33: 516-524, 2009.

88. Meade KG, O'Gorman GM, Hill EW, Narciandi F, Agaba M, Kemp SJ, O'Farrelly C, Machugh DE. Divergent antimicrobial peptide (AMP) and acute phase protein (APP) responses to Trypanosoma congolense infection in trypanotolerant and trypanosusceptible cattle. Mol Immunol 2009

89. Mei HF, Jin XB, Zhu JY, Zeng AH, Wu Q, Lu XM, Li XB, Shen J. beta-defensin 2 as an adjuvant promotes anti-melanoma immune responses and inhibits the growth of implanted murine melanoma in vivo. PLoS One 7: e31328, 2012.

90. Menendez A, Ferreira RB, Finlay BB. Defensins keep the peace too. Nat Immunol 11: 49-50.

91. Meyerholz DK, Kawashima K, Gallup JM, Grubor B, Ackermann MR. Expression of select immune genes (surfactant proteins A and D, sheep beta defensin 1 , and toll-like receptor 4 ) by respiratory epithelia is developmentally regulated in the preterm neonatal lamb. Dev Comp Immunol 30: 1060-1069, 2006.

92. Morrison G, Kilanowski F, Davidson D, Dorin J. Characterization of the mouse beta defensin 1, Defb1, mutant mouse model. Infect Immun 70: 3053-3060, 2002.

93. Morrison GM, Semple CA, Kilanowski FM, Hill RE, Dorin JR. Signal sequence conservation and mature peptide divergence within subgroups of the murine beta-defensin gene family. Mol Biol Evol 20: 460-470, 2003

94. Moser C, Weiner DJ, Lysenko E, Bals R, Weiser JN, Wilson JM. beta-Defensin 1 contributes to pulmonary innate immunity in mice. Infect Immun 70: 3068-3072, 2002.

95. Nagaoka I, Hirota S, Yomogida S, Ohwada A, Hirata M. Synergistic actions of antibacterial neutrophil defensins and cathelicidins. Inflamm Res 49: 73-79, 2000

96. Narciandi F, Lloyd A, Meade KG, O'Farrelly C. A novel subclass of bovine beta-defensins links reproduction and immunology. Reprod Fertil Dev [Epub ahead of print].

97. Narciandi F, Lloyd AT, Chapwanya A, O'Farrelly C, Meade KG. Reproductive tissue-specific expression profiling and genetic variation across a 19 gene bovine $\beta$-defensin cluster. Immunogenetics 63: 641651, 2011.

98. Nickel D, Busch M, Mayer D, Hagemann B, Knoll V, Stenger S. Hypoxia triggers the expression of human beta defensin 2 and antimicrobial activity against Mycobacterium tuberculosis in human macrophages. J Immunol 188: 4001-4007, 2012.

99. Niyonsaba F, Ogawa H, Nagaoka I. Human beta-defensin-2 functions as a chemotactic agent for tumour necrosis factor-alpha-treated human neutrophils. Immunology 111: 273-281, 2004.

100. Ouellette AJ. Paneth cell alpha-defensin synthesis and function. Curr Top Microbiol Immunol 306: 1-25, 2006.
101. Patil AA, Cai Y, Sang Y, Blecha F, Zhang G. Cross-species analysis of the mammalian beta-defensin gene family: presence of syntenic gene clusters and preferential expression in the male reproductive tract. Physiol Genomics 23: 5-17, 2005.

102. Peschel A, Sahl HG. The co-evolution of host cationic antimicrobial peptides and microbial resistance. Nat Rev Microbiol 4: 529-536, 2006.

103. Peyssonnaux C, Datta V, Cramer T, Doedens A, Theodorakis EA, Gallo RL, Hurtado-Ziola N, Nizet V, Johnson RS. HIF-1alpha expression regulates the bactericidal capacity of phagocytes. J Clin Invest 115 : 1806-1815, 2005.

104. Radhakrishnan Y, Fares MA, French FS, Hall SH. Comparative genomic analysis of a mammalian beta-defensin gene cluster. Physiol Genomics 30: 213-222, 2007.

105. Raj PA, Dentino AR. Current status of defensins and their role in innate and adaptive immunity. FEMS Microbiol Lett 206: 9-18, 2002.

106. Rivas-Santiago B, Cervantes-Villagrana A, Sada E, HernandezPando R. Expression of beta defensin 2 in experimental pulmonary tuberculosis: tentative approach for vaccine development. Arch Med Res 43: 324-328, 2012.

107. Rivas-Santiago CE, Rivas-Santiago B, Leon DA, Castaneda-Delgado J, Hernandez Pando R. Induction of beta-defensins by L-isoleucine as novel immunotherapy in experimental murine tuberculosis. Clin Exp Immunol 164: 80-89, 2011.

108. Rohrl J, Yang D, Oppenheim JJ, Hehlgans T. Human beta-defensin 2 and 3 and their mouse orthologs induce chemotaxis through interaction with CCR2. J Immunol 184: 6688-6694, 2010.

109. Roosen S, Exner K, Paul S, Schroder JM, Kalm E, Looft C. Bovine beta-defensins: identification and characterization of novel bovine betadefensin genes and their expression in mammary gland tissue. Mamm Genome 15: 834-842, 2004.

110. Ryan LK, Rhodes J, Bhat M, Diamond G. Expression of beta-defensin genes in bovine alveolar macrophages. Infect Immun 66: 878-881, 1998.

111. Sahl HG, Pag U, Bonness S, Wagner S, Antcheva N, Tossi A. Mammalian defensins: structures and mechanism of antibiotic activity. $J$ Leukoc Biol 77: 466-475, 2005.

112. Salzman NH, Hung K, Haribhai D, Chu H, Karlsson-Sjoberg J, Amir E, Teggatz P, Barman M, Hayward M, Eastwood D, Stoel M, Zhou Y, Sodergren E, Weinstock GM, Bevins CL, Williams CB, Bos NA. Enteric defensins are essential regulators of intestinal microbial ecology. Nat Immunol 11: 76-83, 2010.

113. Sass V, Schneider T, Wilmes M, Korner C, Tossi A, Novikova N, Shamova O, Sahl HG. Human beta-defensin 3 inhibits cell wall biosynthesis in Staphylococci. Infect Immun 78: 2793-2800, 2010.

114. Schaller-Bals S, Schulze A, Bals R. Increased levels of antimicrobial peptides in tracheal aspirates of newborn infants during infection. Am J Respir Crit Care Med 165: 992-995, 2002.

115. Schonwetter BS, Stolzenberg ED, Zasloff MA. Epithelial antibiotics induced at sites of inflammation. Science 267: 1645-1648, 1995.

116. Schroder JM, Harder J. Human beta-defensin-2. Int J Biochem Cell Biol 31: 645-651, 1999.

117. Schutte BC, McCray PB Jr. beta-Defensins in lung host defense. Annu Rev Physiol 64: 709-748, 2002.

118. Selsted ME, Brown DM, DeLange RJ, Harwig SS, Lehrer RI. Primary structures of six antimicrobial peptides of rabbit peritoneal neutrophils. J Biol Chem 260: 4579-4584, 1985.

119. Selsted ME, Harwig SS, Ganz T, Schilling JW, Lehrer RI. Primary structures of three human neutrophil defensins. J Clin Invest 76: 14361439,1985

120. Selsted ME, Ouellette AJ. Mammalian defensins in the antimicrobial immune response. Nat Immunol 6: 551-557, 2005.

121. Selsted ME, Tang YQ, Morris WL, McGuire PA, Novotny MJ, Smith W, Henschen AH, Cullor JS. Purification, primary structures, and antibacterial activities of beta-defensins, a new family of antimicrobial peptides from bovine neutrophils. J Biol Chem 268: 6641-6648, 1993.

122. Semple CA, Gautier P, Taylor K, Dorin JR. The changing of the guard: Molecular diversity and rapid evolution of beta-defensins. Mol Divers 10: 575-584, 2006.

123. Semple CA, Rolfe M, Dorin JR. Duplication and selection in the evolution of primate beta-defensin genes. Genome Biol 4: R31, 2003.

124. Semple CA, Taylor K, Eastwood H, Barran PE, Dorin JR. Betadefensin evolution: selection complexity and clues for residues of functional importance. Biochem Soc Trans 34: 257-262, 2006. 
125. Semple F, MacPherson H, Webb S, Cox SL, Mallin LJ, Tyrrell C, Grimes GR, Semple CA, Nix MA, Millhauser GL, Dorin JR. Human beta-defensin 3 affects the activity of pro-inflammatory pathways associated with MyD88 and TRIF. Eur J Immunol 41: 3291-3300, 2011.

126. Sheldon IM, Cronin J, Goetze L, Donofrio G, Schuberth HJ. Defining postpartum uterine disease and the mechanisms of infection and immunity in the female reproductive tract in cattle. Biol Reprod 81: 1025-1032, 2009.

127. Sheldon IM, Williams EJ, Miller AN, Nash DM, Herath S. Uterine diseases in cattle after parturition. Vet J 176: 115-121, 2008.

128. Shi J, Zhang G, Wu H, Ross C, Blecha F, Ganz T. Porcine epithelial beta-defensin 1 is expressed in the dorsal tongue at antimicrobial concentrations. Infect Immun 67: 3121-3127, 1999.

129. Silverstein KA, Graham MA, Paape TD, VandenBosch KA. Genome organization of more than 300 defensin-like genes in Arabidopsis. Plant Physiol 138: 600-610, 2005.

130. Singh PK, Jia HP, Wiles K, Hesselberth J, Liu L, Conway BA, Greenberg EP, Valore EV, Welsh MJ, Ganz T, Tack BF, McCray PB Jr. Production of beta-defensins by human airway epithelia. Proc Natl Acad Sci USA 95: 14961-14966, 1998.

131. Sorensen OE, Borregaard N, Cole AM. Antimicrobial peptides in innate immune responses. Contrib Microbiol 15: 61-77, 2008.

132. Spoor LE, McAdam PR, Weinert LA, Rambaut A, Hasman H, Aarestrup FM, Kearns AM, Larsen AR, Skov RL, Fitzgerald JR. Livestock origin for a human pandemic clone of community-associated methicillin-resistant Staphylococcus aureus. MBio 4: e00356-13, 2013.

133. Sunkara LT, Achanta M, Schreiber NB, Bommineni YR, Dai G, Jiang W, Lamont S, Lillehoj HS, Beker A, Teeter RG, Zhang G. Butyrate enhances disease resistance of chickens by inducing antimicrobial host defense peptide gene expression. PLoS One 6: e27225, 2011.

134. Swanson K, Gorodetsky S, Good L, Davis S, Musgrave D, Stelwagen K, Farr V, Molenaar A. Expression of a beta-defensin mRNA, lingual antimicrobial peptide, in bovine mammary epithelial tissue is induced by mastitis. Infect Immun 72: 7311-7314, 2004.

135. Takeuchi H, Higashiyama T. A species-specific cluster of defensin-like genes encodes diffusible pollen tube attractants in Arabidopsis. PLoS Biol 10: e1001449, 2012.

136. Tarver AP, Clark DP, Diamond G, Russell JP, Erdjument-Bromage H, Tempst P, Cohen KS, Jones DE, Sweeney RW, Wines M, Hwang S, Bevins CL. Enteric beta-defensin: molecular cloning and characterization of a gene with inducible intestinal epithelial cell expression associated with Cryptosporidium parvum infection. Infect Immun 66: 1045-1056, 1998.

137. Tennessen JA. Molecular evolution of animal antimicrobial peptides: widespread moderate positive selection. J Evol Biol 18: 1387-1394, 2005 .

138. Tollner TL, Venners SA, Hollox EJ, Yudin AI, Liu X, Tang G, Xing H, Kays RJ, Lau T, Overstreet JW, Xu X, Bevins CL, Cherr GN. A common mutation in the defensin DEFB126 causes impaired sperm function and subfertility. Sci Transl Med 3: 92ra65, 2011.

139. Tollner TL, Yudin AI, Tarantal AF, Treece CA, Overstreet JW, Cherr GN. Beta-defensin 126 on the surface of macaque sperm mediates attachment of sperm to oviductal epithelia. Biol Reprod 78: 400-412, 2008.

140. Tollner TL, Yudin AI, Treece CA, Overstreet JW, Cherr GN. Macaque sperm coating protein DEFB126 facilitates sperm penetration of cervical mucus. Hum Reprod 23: 2523-2534, 2008.

141. Tollner TL, Yudin AI, Treece CA, Overstreet JW, Cherr GN. Macaque sperm release ESP13.2 and PSP94 during capacitation: the absence of ESP132 is linked to sperm-zona recognition and binding. Mol Reprod Dev 69: 325-337, 2004.

142. Tomley FM, Shirley MW. Livestock infectious diseases and zoonoses. Philos Trans R Soc Lond B Biol Sci 364: 2637-2642, 2009.

143. Turner TT, Hartmann PK, Howards SS. In vivo sodium, potassium, and sperm concentrations in the rat epididymis. Fertil Steril 28: 191-194, 1977.

144. Voss E, Wehkamp J, Wehkamp K, Stange EF, Schroder JM, Harder J. NOD2/CARD15 mediates induction of the antimicrobial peptide human beta-defensin-2. J Biol Chem 281: 2005-2011, 2006.

145. Whelehan CJ, Meade KG, Eckersall PD, Young FJ, O'Farrelly C. Experimental Staphylococcus aureus infection of the mammary gland induces region-specific changes in innate immune gene expression. Vet Immunol Immunopathol 140: 181-189, 2011.

146. Whittington CM, Papenfuss AT, Bansal P, Torres AM, Wong ES, Deakin JE, Graves T, Alsop A, Schatzkamer K, Kremitzki C, Pon- ting CP, Temple-Smith P, Warren WC, Kuchel PW, Belov K. Defensins and the convergent evolution of platypus and reptile venom genes. Genome Res 18: 986-994, 2008.

147. Wilmes M, Cammue BP, Sahl HG, Thevissen K. Antibiotic activities of host defense peptides: more to it than lipid bilayer perturbation. Nat Prod Rep 28: 1350-1358, 2011.

148. Wojdak-Maksymiec K, Kmiec M, Zukiewicz A. Associations between defensin polymorphism and somatic cell count in milk and milk utility traits in Jersey dairy cows. J Vet Med A Physiol Pathol Clin Med 53: 495-500, 2006.

149. Wu Z, Hoover DM, Yang D, Boulegue C, Santamaria F, Oppenheim JJ, Lubkowski J, Lu W. Engineering disulfide bridges to dissect antimicrobial and chemotactic activities of human beta-defensin 3. Proc Natl Acad Sci USA 100: 8880-8885, 2003.

150. Xiao Y, Hughes AL, Ando J, Matsuda Y, Cheng JF, Skinner-Noble D, Zhang G. A genome-wide screen identifies a single beta-defensin gene cluster in the chicken: implications for the origin and evolution of mammalian defensins. BMC Genomics 5: 56, 2004.

151. Yang D, Biragyn A, Kwak LW, Oppenheim JJ. Mammalian defensins in immunity: more than just microbicidal. Trends Immunol 23: 291-296, 2002.

152. Yang D, Chertov O, Bykovskaia SN, Chen Q, Buffo MJ, Shogan J, Anderson M, Schroder JM, Wang JM, Howard OM, Oppenheim JJ. Beta-defensins: linking innate and adaptive immunity through dendritic and T cell CCR6. Science 286: 525-528, 1999.

153. Yang D, Chertov O, Oppenheim JJ. Participation of mammalian defensins and cathelicidins in anti-microbial immunity: receptors and activities of human defensins and cathelicidin (LL-37). J Leukoc Biol 69: 691-697, 2001.

154. Yang J, Sang Y, Meade KG, Ross C. The role of oct-1 in the regulation of tracheal antimicrobial peptide (TAP) and lingual antimicrobial peptide (LAP) expression in bovine mammary epithelial cells. Immunogenetics 63: 715-725, 2011.

155. Yeaman MR, Yount NY. Unifying themes in host defence effector polypeptides. Nat Rev Microbiol 5: 727-740, 2007.

156. Yeung AT, Gellatly SL, Hancock RE. Multifunctional cationic host defence peptides and their clinical applications. Cell Mol Life Sci 68: 2161-2176, 2011.

157. Yudin AI, Generao SE, Tollner TL, Treece CA, Overstreet JW, Cherr GN. Beta-defensin 126 on the cell surface protects sperm from immunorecognition and binding of anti-sperm antibodies. Biol Reprod 73: 1243-1252, 2005.

158. Yudin AI, Tollner TL, Li MW, Treece CA, Overstreet JW, Cherr GN. ESP13.2, a member of the beta-defensin family, is a macaque sperm surface-coating protein involved in the capacitation process. Biol Reprod 69: 1118-1128, 2003.

159. Yudin AI, Treece CA, Tollner TL, Overstreet JW, Cherr GN. The carbohydrate structure of DEFB126, the major component of the cynomolgus Macaque sperm plasma membrane glycocalyx. J Membr Biol 207: 119-129, 2005.

160. Zasloff M. Antimicrobial peptides of multicellular organisms. Nature 415: 389-395, 2002.

161. Zasloff M. Inducing endogenous antimicrobial peptides to battle infections. Proc Natl Acad Sci USA 103: 8913-8914, 2006.

162. Zhao C, Wang I, Lehrer RI. Widespread expression of beta-defensin hBD-1 in human secretory glands and epithelial cells. FEBS Lett 396: 319-322, 1996.

163. Zhao Y, Diao H, Ni Z, Hu S, Yu H, Zhang Y. The epididymis-specific antimicrobial peptide beta-defensin 15 is required for sperm motility and male fertility in the rat (Rattus norvegicus). Cell Mol Life Sci 68: 697-708, 2011.

164. Zopfgen A, Priem F, Sudhoff F, Jung K, Lenk S, Loening SA, Sinha P. Relationship between semen quality and the seminal plasma components carnitine, alpha-glucosidase, fructose, citrate and granulocyte elastase in infertile men compared with a normal population. Hum Reprod 15: 840-845, 2000.

165. Zorn B, Virant-Klun I, Meden-Vrtovec H. Semen granulocyte elastase: its relevance for the diagnosis and prognosis of silent genital tract inflammation. Hum Reprod 15: 1978-1984, 2000.

166. Zou J, Mercier C, Koussounadis A, Secombes C. Discovery of multiple beta-defensin like homologues in teleost fish. Mol Immunol 44: 638-647, 2007. 